\title{
Hvorfor velger noen foreldre å ikke vaksinere barna sine?
}

To modeller kan hjelpe oss med å forstå hvorfor noen foreldre velger å ikke vaksinere barna sine. For noen foreldre er helse et individuelt valg, mens andre mangler sosial tilhørighet.

\section{Claire Glenton}

Seniorforsker og direktør

Folkehelseinstituttet og Cochrane Norge

Vaksine barnevaksinasjonsprogrammet Vaksineskeptiker

Den første modellen dreier seg i hovedtrekk om foreldrenes oppmerksomhet på individet fremfor hensynet til samfunnet. I den andre modellen er foreldrenes vaksinemotstand et uttrykk for at de føler seg sosialt ekskludert. Det viser en Cochrane-oversikt.

\section{Hva sier forskningen?}

I systematiske oversikter samles og vurderes tilgjengelig forskning. I denne systematiske Cochraneoversikten var målet å oppsummere kvalitative studier som utforsket foreldres holdninger til og beslutninger om barnevaksiner. 
Resultatene viser at det er mange komplekse faktorer som påvirker foreldres vaksineholdninger og beslutninger. Oversiktsforfatterne delte disse faktorene inn i fire temaer:

- Foreldre blir påvirket av sine oppfatninger om helse og sykdom generelt, deriblant sine oppfatninger om barns helse og sykdom.

- Mange foreldre påvirkes også av menneskene de omgås sosialt med. Å dele bestemte oppfatninger om vaksiner med andre hjelper også noen foreldre med å skape sosiale relasjoner, noe som igjen kan styrke deres vaksineholdninger og -beslutninger.

- Foreldre blir også påvirket av politiske temaer og hendelser og deres tillit (eller manglende tillit) til myndigheter, eksperter og andre som har tilknytning til vaksinasjonsprogrammer.

- Foreldre påvirkes av tilgangen til og erfaringer med vaksinasjonstjenester.

Oversiktsforfatterne utviklet to konsepter for å skissere mulige forklaringer på hvorfor foreldre ikke $\emptyset$ nsket å vaksinere barna sine. Det første konseptet, neoliberal logikk-konseptet, beskriver hvordan noen foreldre, oftest fra høyinntektsland, ser på helse og helsebeslutninger som et individuelt valg og et individuelt ansvar som bør baseres på vurderinger av individets risiko.

\section{«Noen foreldre, oftest fra høyinntektsland, ser på helse og helsebeslutninger som et individuelt valg.»}

Å sette individet i sentrum kan for noen foreldre dermed komme i konflikt med vaksinasjonsprogrammer der den generelle risikoen, folkehelsen og samfunnsgevinsten fremheves. Utfallet av en slik konflikt kan dermed bli at foreldrene velger å ikke vaksinere barna sine. 
Det andre konseptet, sosial eksklusjon-konseptet, beskriver hvordan noen foreldre, ofte fra lav- og mellominntektsland, er mindre villige til å vaksinere barna sine fordi de føler seg sosialt ekskludert. Sosial eksklusjon uttrykkes blant annet gjennom fattigdom, mangel på politisk makt, diskriminering og lite tilgjengelige helsetjenester.

\section{«Noen foreldre, ofte fra lav- og mellominntektsland, er mindre villige til å vaksinere barna sine fordi de føler seg sosialt ekskludert.»}

Slike forhold kan skade foreldrenes tillit til myndighetene, skape følelser av harme og isolasjon og føre til at foreldrene er lite motivert til å bruke offentlige tjenester som er av dårlig kvalitet og lite tilgjengelige.

Da vaksinasjonsprogrammer er i regi av myndighetene, kan det å nekte å vaksinere barna sine være en slags motstandsytring til samfunnet de lever i. Valget om ikke å vaksinere barna sine kan også ha som motivasjon å skape endring i samfunnet. Andre, mer konkrete årsaker bak manglende vaksineoppmøte er tid, kostnader og frustrasjonen det skaper.

\section{Bakgrunn}

Barnevaksiner er blant de mest effektive metodene som finnes for å forebygge alvorlig sykdom og død blant barn. Likevel er det mange barn som ikke mottar de anbefalte vaksinene. I Norge er barnevaksinasjonsdekningen generelt $h \varnothing y$, men det finnes likevel lommer av uvaksinerte barn flere steder i landet. 
I noen tilfeller skyldes dette at foreldre aktivt velger å ikke vaksinere sine barn. Kvalitativ forskning unders $\varnothing$ ker hvordan folk opplever verden rundt seg, og er derfor velegnet til å unders $\varnothing$ ke hva det er som påvirker foreldres holdninger og beslutninger om barnevaksinasjoner, og hvorfor noen foreldre ikke tar imot disse vaksinene på vegne av sine barn.

\section{Hva er denne informasjonen basert på?}

Forfatterne av Cochrane-oversikten gjorde et s $\varnothing \mathrm{k} \mathrm{i}$ aktuelle forskningsdatabaser i juli 2020 og inkluderte 27 kvalitative studier.

\begin{tabular}{|c|c|c|}
\hline & Hva lette de etter? & Hva fant de? \\
\hline Populasjon & $\begin{array}{l}\text { Studier om foreldre, vordende foreldre (gravide } \\
\text { kvinner og deres partnere) og andre med } \\
\text { omsorgsplikt for barn. }\end{array}$ & $\begin{array}{l}\text { Alle de } 27 \text { studiene inkluderte foreldre og andre med omsorg for barn, } \\
\text { for eksempel bestemødre. I } 12 \text { av studiene var kun mødre inkludert. } \\
\text { Studiedeltakerne i de } 27 \text { studiene var fra forskjellige sosioøkonomiske } \\
\text { grupper. To av studiene fokuserte på minoritetsgrupper (ortodokse } \\
\text { protestanter i Nederland og romer/reisende i England). Fem av studiene } \\
\text { omhandlet foreldre som ikke hadde vaksinert sine barn. }\end{array}$ \\
\hline Tema & $\begin{array}{l}\text { Studier som omhandlet vaksiner som anbefales } \\
\text { av WHO, og som tilbys rutinemessig til barn } \\
\text { under seks år (f.eks. BCG [tuberkulose], hepB, } \\
\text { polio, DPT, Hib, PCV, MMR). Studier av vaksiner } \\
\text { for barn over } 6 \text { år (f.eks. HPV), eller studier av } \\
\text { hypotetiske eller fremtidige vaksiner ble ikke tatt } \\
\text { med. }\end{array}$ & $\begin{array}{l}\text { Tre av studiene satte søkelyset på poliovaksiner. De resterende } 24 \\
\text { studiene så på alle typer barnevaksiner. }\end{array}$ \\
\hline Setting & Studier fra alle settinger. & $\begin{array}{l}\text { Studiene var fra Afrika, Nord- og Sør-Amerika, Sørøst-Asia, Europa og } \\
\text { Australia og dekket høy-, middel- og lavinntektsland med både urbane og } \\
\text { rurale settinger. }\end{array}$ \\
\hline $\begin{array}{l}\text { Tillit til } \\
\text { resultatet }\end{array}$ & $\begin{array}{l}\text { GRADE-CERQual ble brukt til å vurdere tilliten til } \\
\text { oversiktsfunnene. }\end{array}$ & $\begin{array}{l}\text { Oversiktsforfatterne hadde stor tillit til sju av de nitten funnene, middels } \\
\text { tillit til åtte av funnene, og lav tillit til fire av funnene. } \\
\text { Hovedårsaken til svekket tillit var metodologiske problemer med } \\
\text { enkeltstudiene (for eksempel mangel på refleksivitet og dårlig } \\
\text { rapportering av datautvalg- og analysemetoder), eller fordi } \\
\text { enkeltstudiene bare dekket noen typer settinger eller } \\
\text { befolkningsgrupper. }\end{array}$ \\
\hline
\end{tabular}

\section{Systematisk oversikt}

I systematiske oversikter s $\varnothing$ ker man etter og oppsummerer studier som svarer på et konkret forskningsspørsmål. Studiene blir funnet, vurdert og oppsummert ved å bruke en systematisk og forhåndbeskrevet fremgangsmåte (les mer på Cochrane Consumer Network).

\section{Tillit til resultatet (GRADE)}

Når vi oppsummerer studier og presenterer et resultat, er det viktig å si noe om hvor mye tillit vi kan ha til dette. Det handler om hvor trygge vi kan være på at resultatet gjenspeiler virkeligheten. GRADE er et system vi bruker for å kunne bedømme tilliten til resultatet. I GRADE vurderer vi blant annet 
- hvor godt studiene er gjennomført

- om studiene har nok data

- om studiene viser et tydelig mønster

- hvor relevante studiene er.

\section{Kilde}

Cooper S, Schmidt B-M, Sambala EZ, Swartz A, Colvin CJ, Leon N, et al. Factors that influence parents' and informal caregivers' views and practices regarding routine childhood vaccination: a qualitative evidence synthesis. Cochrane Database of Systematic Reviews. 2021; (10):art.nr.: CDo13265. DOI: 10.1002/14651858.CDO13265.pub2

Les hele Cochrane-oversikten her: Factors that influence parents' and informal caregivers' views and practices regarding routine childhood vaccination: a qualitative evidence synthesis 